\title{
Towards a Just Energy Transition, Barriers and Opportunities for Positive Energy District Creation in Spain
}

\author{
Adam X. Hearn $1, *$ (D) and Raul Castaño-Rosa ${ }^{2,3}$ \\ 1 Sustainability Research Group, University of Basel, CH-4051 Basel, Switzerland \\ 2 Appropriate Technologies for Sustainable Development Group, Universidad Carlos III de Madrid, \\ 28903 Madrid, Spain; raul.castanodelarosa@tuni.fi \\ 3 Faculty of Built Environment, Tampere University, Korkeakoulunkatu 1, 33720 Tampere, Finland \\ * Correspondence: adam.hearn@unibas.ch; Tel.: +49-152-5230-0448
}

Citation: Hearn, A.X.; Castaño-Rosa, R. Towards a Just Energy Transition, Barriers and Opportunities for Positive Energy District Creation in Spain. Sustainability 2021, 13, 8698. https://doi.org/10.3390/su13168698

Academic Editor: Alessandro Franco

Received: 30 June 2021

Accepted: 29 July 2021

Published: 4 August 2021

Publisher's Note: MDPI stays neutral with regard to jurisdictional claims in published maps and institutional affiliations.

Copyright: (C) 2021 by the authors. Licensee MDPI, Basel, Switzerland. This article is an open access article distributed under the terms and conditions of the Creative Commons Attribution (CC BY) license (https:// creativecommons.org/licenses/by/ $4.0 /)$.

\begin{abstract}
To mitigate the effects of climate change, the European Commission created a Strategic Energy Technology Plan committing to forming 100 Positive Energy Districts (PEDs) by 2025. These are considered to potentially be major instruments for decarbonization in a just transition. This plan has led to some districts being defined as PEDs, although none have fully met the criteria to be a PED yet. Research shows that new forms of energy ownership and production, as could potentially be found in PEDs, could help reduce energy poverty, which affects a significant segment of the population, as households can reduce their energy expenditure as well as improve their energy behavior. This paper set out to shed light on the PED landscape, investigating the barriers and opportunities to PED creation in Spain and its potential to mitigate energy poverty. We conducted a literature review on community-owned energy in Spain, followed with expert interviews (energy researchers, stakeholders, and NGOs) who focus on sustainability issues in Spain. Results show a number of barriers (lack of knowledge and awareness, and lack of trust from consumers) and opportunities connected with the creation of PEDs. In conclusion, policymaker engagement and support play a key role in successfully implementing PEDs.
\end{abstract}

Keywords: Positive Energy Districts (PEDs); Local Energy Communities (LECs); energy justice; energy transition; energy poverty

\section{Introduction}

A significant decline in the costs associated with PV production and innovative PV efficiency improvements, coupled with the high number of solar days makes a strong case for PV energy in Spain [1] to meet and exceed national energy requirements [2]. However, until 2018, regressive legislation (specifically RD900/2015) protected dominant market interests and penalized PV energy production. The Royal Decree 244/2019 (RD244) ended taxation on self-production, and also defined the conditions for creating energy communities in Spain [1].

In a concerted attempt to speed up the decarbonization of urban areas within the EU, a project to establish 100 Positive Energy Districts (PEDs) in Europe by the year 2025 [3] was set in motion by the Joint Programming Initiative Urban Europe [4]. PEDs are defined as highly energy efficient districts that are wholly powered by Renewably Energy Technology (henceforth RET), and produce a yearly net surplus of energy, whilst also offering affordable living for residents [5]. The concept of PEDs arose as a natural extension from pre-existing low-carbon developments, such as Positive Energy Buildings [4] and Positive Energy Blocks [6], and is seen as a step towards Nearly Zero Energy Cities (NZECs) [7] and Positive Energy Cities (PECs). The creation of an initial 100 PEDs across Europe also focuses on replicability as these have been identified as a potentially significant tool in decarbonizing urban areas in Europe, which could be further expanded once these have been fully evaluated [5]. A PED booklet containing 61 different projects in Europe [4,8] 
includes four in Spain; Atelier project in Bilbao (in implementation [9]), Paterna, Valencia (in planning), Mieres, Asturias District heating (implemented towards PED), and Mostoles Madrid Ecoenergias District Heating (implemented towards PED).

There are potentially three different types of PEDs. Autonomous PEDs are entirely self-sufficient and produce all their energy on-site, whilst Dynamic PEDs may import energy, but produce a net surplus on a yearly basis. Virtual PEDs incorporate RET, which is located outside of the boundaries of the PED [10]. Whilst it is clear that PEDs are to be renewably powered, and the topic of where energy production is to be situated has been examined [10], novel forms of community energy ownership could support PED development.

Energy communities in the form of Renewable Energy Communities (RECs) and Citizen Energy Communities (CECs) are enshrined in EU directives [11]. PEDs, CECs and RECs have similar goals of reducing emissions, as well as increasing active citizen participation in decentralizing energy markets, leading to the terms often being wrongly used interchangeably (see Table 1). Both RECs and CECs are often referred to as Local Energy Communities (Comunidades Energéticas in Spanish, henceforth LECs), but the term LEC is more closely aligned with the legal term REC. Table 1 (below) summarizes the main similarities and differences between prosumers, energy cooperatives, RECs, CECs and PEDs.

Table 1. Differences between Prosumers, RECs, CECs and PEDs (Authors own elaboration).

\begin{tabular}{|c|c|c|c|c|c|}
\hline & $\begin{array}{l}\text { Self-Consumption/ } \\
\text { Prosumers [12] }\end{array}$ & $\begin{array}{c}\text { Energy } \\
\text { Cooperative [13] }\end{array}$ & $\begin{array}{l}\text { Renewable Energy } \\
\text { Community } \\
\text { (REC) [14] }\end{array}$ & $\begin{array}{l}\text { Citizen Energy } \\
\text { Community } \\
\text { (CEC) [15] }\end{array}$ & $\begin{array}{c}\text { Positive Energy } \\
\text { District (PED) [10] }\end{array}$ \\
\hline Membership & $\begin{array}{l}\text { Household, or within } \\
\text { same building }\end{array}$ & $\begin{array}{c}\text { Multiple } \\
\text { households }\end{array}$ & $\begin{array}{c}\text { Individuals, local } \\
\text { authorities, } \\
\text { enterprises, but must } \\
\text { not be primary com- } \\
\text { mercial/professional } \\
\text { activity. Must be } \\
\text { accessible to } \\
\text { low-income } \\
\text { households }\end{array}$ & $\begin{array}{c}\text { Individuals, local } \\
\text { authorities, } \\
\text { enterprises }\end{array}$ & $\begin{array}{l}\text { Can incorporate } \\
\text { households, } \\
\text { individuals, local } \\
\text { authorities, } \\
\text { enterprises. } \\
\text { Must be inclusive }\end{array}$ \\
\hline $\begin{array}{l}\text { Location of energy } \\
\text { production }\end{array}$ & On the property & Can be anywhere & Must be local & Can be anywhere & $\begin{array}{c}\text { Must be local for } \\
\text { Autonomous and } \\
\text { Dynamic PEDS, but } \\
\text { can be anywhere for } \\
\text { Virtual PEDs }\end{array}$ \\
\hline $\begin{array}{l}\text { Innovations/ } \\
\text { Technologies }\end{array}$ & $\begin{array}{l}\text { Mainly PV, solar hot } \\
\text { water, energy storage, } \\
\text { heatpumps }\end{array}$ & $\begin{array}{l}\text { Bottom up } \\
\text { network of } \\
\text { sustainable } \\
\text { innovation }\end{array}$ & $\begin{array}{c}\text { Only renewable } \\
\text { energy } \\
\text { (May not meet full } \\
\text { demand) }\end{array}$ & $\begin{array}{l}\text { Any form of energy } \\
\text { (May not meet full } \\
\text { demand) }\end{array}$ & $\begin{array}{l}\text { Only renewables } \\
\text { (Must aim to } \\
\text { eventually exceed } \\
\text { demand) }\end{array}$ \\
\hline $\begin{array}{l}\text { Legally permitted } \\
\text { activities in energy } \\
\text { sector }\end{array}$ & $\begin{array}{l}\text { Production, consumption } \\
\text { of own energy, sale of } \\
\text { excess to grid or } \\
\text { Peer-to-peer trading } \\
\text { Installed capacity per } \\
\text { household/user is } \\
\text { limited unless they are in } \\
\text { a cooperative or a } \\
\text { CEC [16] }\end{array}$ & $\begin{array}{l}\text { Production and } \\
\text { Marketing }\end{array}$ & $\begin{array}{l}\text { All segments of the } \\
\text { energy chain }\end{array}$ & $\begin{array}{c}\text { May engage in } \\
\text { generation, } \\
\text { distribution, supply, } \\
\text { consumption, } \\
\text { aggregation, energy } \\
\text { storage, energy } \\
\text { efficiency services or } \\
\text { charging services for } \\
\text { electric vehicles or } \\
\text { provide other energy } \\
\text { services to its } \\
\text { members or } \\
\text { shareholders }\end{array}$ & $\begin{array}{c}\text { Not legally } \\
\text { determined as may } \\
\text { include Prosumers, } \\
\text { RECs and CECs }\end{array}$ \\
\hline
\end{tabular}

The flexibility afforded to PEDs in not having any specified legally permitted activities in the energy sector allows for the inclusion of both RECs and CECs within them. Although there is no requirement for PEDs to include any form of community energy, it is very likely that these will be used to support PED development and they have been linked 
to PEDs in research [17]. However, PEDs may also include individual prosumers, and renewable energy supplied by utilities or energy cooperatives. In this paper we focus on PEDs, and include LECs as we believe these increase the potential for PEDs to form part of a just transition.

The growth of LECs across Europe is no longer isolated to specific countries [18], and there is evidence to show that the number of LECs within the EU has dramatically increased since the Clean Energy for All Europeans package [19] was launched in 2019. Although the distribution of LECs across Europe remains uneven, they are established as important stakeholders in the energy systems of nations such as Germany and Denmark [20], whilst being in early development in others such as Spain, where a public consultation on LECs took place in December 2020 [21,22].

The residential building sector accounts for 18.3\% [23] of energy demand in Spain, and the need to decarbonize this is undisputable. However, the benefits of doing so through the creation of PEDs are manifold. PEDs can potentially bring about significant technical, financial and social benefits as a part of a decentralized energy system [24,25]. On the technical side, a distributed energy system can alleviate pressure on centralized grids, increasing security reliability and resilience in the event of price volatility or energy emergencies [26]. From a financial perspective, although costs per unit and installation costs are liable to vary widely, more companies are likely to be involved, with benefits spread over significantly greater numbers of interested parties, leading to greater financial resilience [27]. In Spain, it is currently cheaper to produce a KWh of energy through PV than purchasing it from the grid [26], making decentralized forms of energy production attractive as an investment to households and communities. Both of these aspects (technological and financial) are equally applicable in the case of prosumers. However, the big difference between individual prosumers and LECs is that for PEDs, shared forms of energy production, management and distribution can be tailored to ensure that energy poverty is mitigated, as well as to assist in the (re)creation of flourishing shared communities that go beyond energy, incorporating other social benefits [28].

Energy poverty refers to a household that is unable to meet its energy needs, and has been identified as a significant problem throughout Europe, including in Mediterranean countries like Spain [29,30]. LECs have been considered from the perspective of energy poverty [25,31], as a tool for mitigating energy poverty [32,33], especially within the Mediterranean, such as in Greece [34,35], Italy [36] and Portugal [37]. From the literature it is clear that LECs are able to identify local energy needs and foster community participation [38], and as such could be utilized as an enduring method to reduce energy poverty. Therefore, LECs can potentially provide free or reduced cost energy and an additional income stream (should energy be sold) for those in energy poverty. On a PED scale, research in Portugal indicates the potential of PEDs as a tool for mitigating energy poverty in the historic district of Alfama in Lisbon [39].

Research in smart energy systems has included different technologies (i.e., energy storage [40]; district heating [41], or the Internet of Things [42]), but there has been little research into LECs or PEDs development in the Spanish context so far. Indeed, in the case of Spain, academic attention has often focused on individual prosumers [43] or energy cooperatives such as Som Energia [13,44-47], largely because legislation has meant that such cooperatives were able to function where LECs were not. Research into LECs and PEDs in Spain is sparse, with little research on their potential effect on energy poverty mitigation or from an energy justice perspective.

In this respect, this research aims at identifying what the existing barriers are to PED creation as part of a just transition in Spain, based on expert interviews with developers of LECs and PEDs, and energy researchers. We detail our methodology below, followed by the framework behind our approach and a literature review. The potential for PEDs to form part of a just energy transition and mitigate EP is discussed using an analysis of the interviews conducted, based on our framework. This is followed by a section on LECs, PEDs and energy poverty, which is seen as a form of capability deprivation [48] that 
encompasses all aspects of the energy justice framework we use. We conclude, providing some policy recommendations for PEDs in the Spanish context.

\section{Materials and Methods}

To address this gap, we first conducted a literature review by using Scopus searches for the terms "Positive Energy Districts"; "Energy Communities" and "Spain"; and "Energy Communities" and "Energy Poverty" (Figure 1), which resulted in the inclusion of thirtynine articles. In addition, we conducted a snowball search of articles related to LECs elsewhere in Europe, together with searches of grey and non-academic literature on PEDs and LECs in Spain. Figure 1 below shows graphically the methodology used for the Scopus literature review.

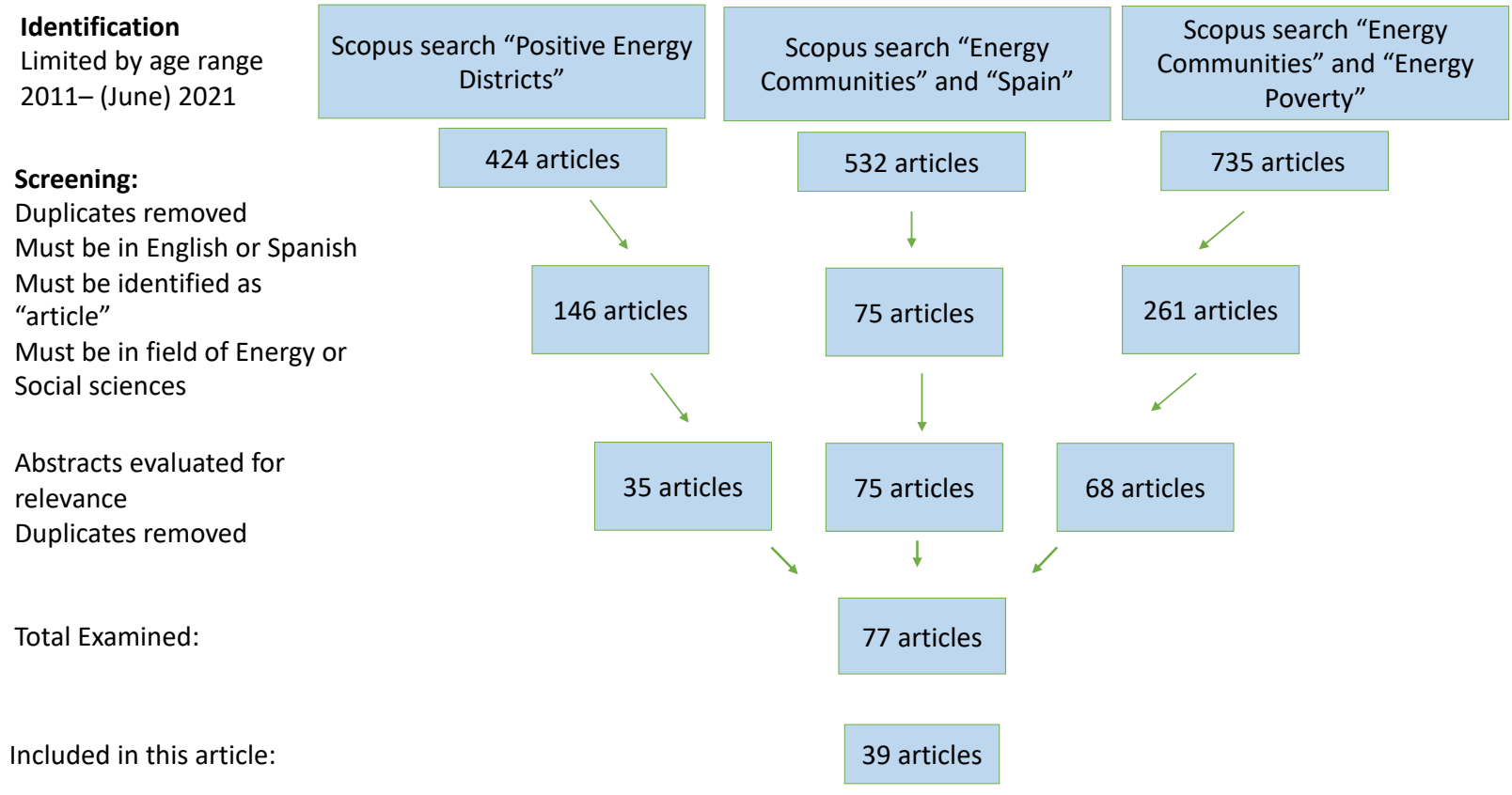

Figure 1. Literature search methodology.

Secondly, potential candidates to interview were initially located online using the four Spanish projects listed in the PED booklet as a starting point, together with a major energy cooperative, Som Energia, which was able to put us in contact with a number of LECs. 13 semi-structured in-depth interviews from thirty to sixty minutes duration, with a total of 16 key stakeholders ( 12 male, 4 female) from LECs, cooperatives, local, regional and national government, private enterprise (PED designers), researchers and NGOs, were conducted (see Table 2). We struggled to get female respondents, which is broadly in line with research indicating that women's viewpoints are often absent or underrepresented in energy transition pathways [49]. Ethical approval for the interviews was granted by the SMART BEEjS consortium. Table 2 provides an overview of the different interviewee typologies according to their main roles.

Interviews were conducted online using the Zoom platform, transcribed and translated before coding and content analysis using MaxQDA2020. Many of those interviewees had multiple roles, such as working for local authorities and LECs, as well as being members of different energy cooperatives. 
Table 2. List of different interviewee typologies.

\begin{tabular}{|c|c|c|c|c|}
\hline Principle Interviewee Role & $\begin{array}{l}\text { Number of } \\
\text { Interviews }\end{array}$ & $\begin{array}{l}\text { Codes Assigned to } \\
\text { Interviewees }\end{array}$ & Region Located in & Gender \\
\hline \multirow{4}{*}{ Researcher: } & \multirow{4}{*}{4} & ER1, & Madrid & Male \\
\hline & & ER2, & Madrid & Female \\
\hline & & ER3, & Castilla y Leon, & Male \\
\hline & & ER4 & Barcelona & Female \\
\hline Public office (i.e., councilor & & $\mathrm{P} 1$, & Madrid & Male \\
\hline for energy and sustainability) & 2 & P2; Mo1, Mo2 & Madrid & Male, Male \\
\hline Energy-related NGO & 1 & NGO1 & Madrid & Male \\
\hline Private firm & 1 & PR1; M1, F1 & Valencia & Male, Female \\
\hline EC organisation & 4 & $\begin{array}{c}\text { EC1, } \\
\text { EC2, } \\
\text { EC3, } \\
\text { EC4:V1, V2 }\end{array}$ & $\begin{array}{c}\text { Andalucia Navarra, } \\
\text { Andalucia } \\
\text { Catalonia }\end{array}$ & $\begin{array}{c}\text { Male, Male, Male } \\
\text { Male, Male }\end{array}$ \\
\hline Cooperative association & 1 & $\mathrm{C} 1$ & Catalonia & Female \\
\hline
\end{tabular}

\section{Literature Review: The Case of Spain}

A prominent framework that has been used to analyze LECs in Spain is the Multilevel Perspective (MLP) [50]. The MLP has been used in some research on LECs in Spain, in which the socio-technical system is divided into niches, regimes, and landscapes $[13,45]$. These form a nested hierarchy in which shared energy initiatives such as cooperatives and LECs are perceived as forming and operating in a niche. Innovations formed in the niche are sometimes able to become a dominant aspect of the regime, depending on their ability to compete with pre-existing forms that dominate the regime (in this case the oligarchy of major energy suppliers). The regime in this case is also under pressure from the landscape level, which refers to the external factors that influence the regime such as climate change and EU directives.

However, in order to ensure the creation of PEDs is justice-informed that they might be a part of a fair and inclusive transition, an energy justice framework may be more feasible.

An energy justice framework incorporating the MLP is put forwards by Jenkins, Sovacool and McCauley [51], and this approach notes the importance of further research that considers non-traditional actors such as users and marginalized groups in transitions. We build on this by incorporating energy poverty, but we consider PEDs to be socio-technical niches [52], which may be routed in technology, but which are also social innovations. Owing to this, we focus on an energy justice approach which is informed by the capability approach (CA) [53]. The CA has been used as a metric for wellbeing and justice in research focusing on LECs in the global South [54-56], as well as on energy justice research that focuses on energy poverty [48] providing a multidimensional definition of energy poverty as a capability deprivation. Ensuring that PEDs are embedded within energy justice, by using a CA based framework, may assist in meeting the European Green Deal requirement of a "just and inclusive" transition [57].

Our approach is to examine different aspects of the physical, economic, social and technical setting through a justice informed lens, which includes the triumvirate of energy justice tenets (distributional, procedural, and recognitional justice [58]), but also includes global, redistributive, intergenerational and intragenerational justice $[59,60]$.

For the case of PEDs, distributional justice focuses on the benefits and burdens of being included in an energy community in terms of where the energy producing technology is placed. We also consider recognitional justice, asking about how inclusive PEDs are/plan to be. Further, we enquire on procedural justice aspects, how decision-making processes are created and to what degree these are transparent in the face of the energy industry in Spain. Additionally, we attempt to understand to what extent intergenerational and intragenerational justice are considered in the forming of PEDs, whilst also raising the question of global justice which is significant when it comes to the extraction of raw materials and the 
production of PV panels [61]. For those that are adversely affected, we question whether restorative justice principles could increase overall support for such projects.

To do this, Figure 2 depicts the framework used for the analysis that incorporates energy justice into the ex-ante assessment of PEDs [59] (Figure 2, below), examining the aforementioned energy justice dimensions considered in terms of opportunity spaces (or Capitals).

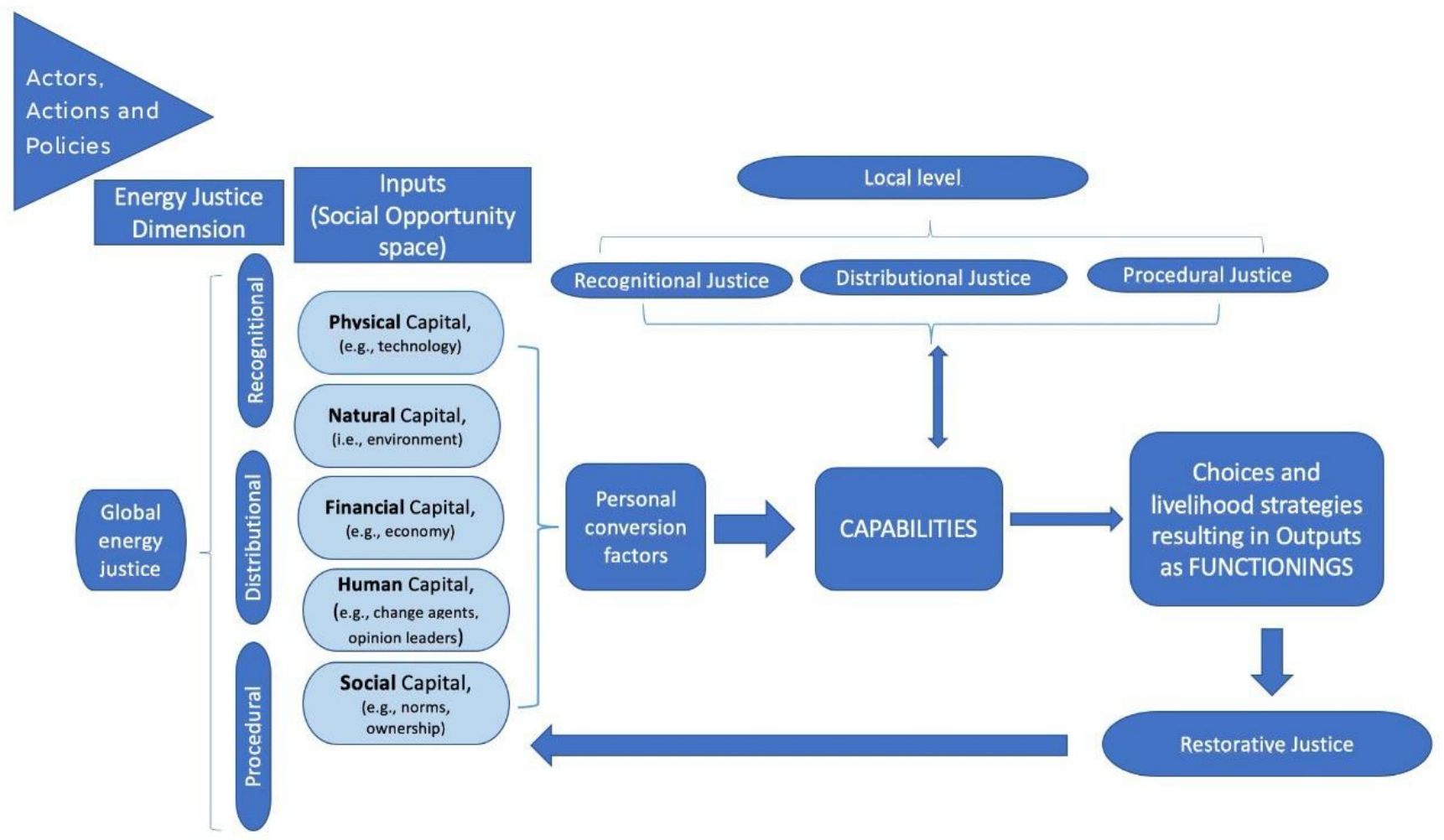

Figure 2. Livelihoods-Capabilities based energy justice framework from Hearn, Sohre and Burger 2021.

Although PEDs are newcomers to the field of energy in Spain, there has been some research into potential barriers and opportunities for new forms of energy ownership in Spain such as cooperatives and LECs, as well as research on an international scale, which may be applicable to PED creation [62]. In terms of barriers, these can be divided into technological, financial, social, political and regulatory. We link these to opportunity spaces within the energy justice framework:

Physical Capital. This refers to issues surrounding the infrastructure and technology available for the PED.

Natural Capital. This focuses on environmental issues that may arise in connection to the PED, and natural barriers and opportunities.

Financial Capital refers to the access and availability of finance, income generating activities and affordability of the PED.

Human Capital examines the knowledge base available for the PED as well as change agents and opinion leaders. Within this we incorporate political and legislative barriers and opportunities.

Social Capital focuses on the social and cultural frame conditions for the PED.

Technical barriers or physical capital include the fact that there has not been much experience in managing reverse power flows from high PV generation in the system [1] and that the increasing number of prosumers (both collective and individual) could lead to overall grid costs increasing [12]. Barriers to Financial capital relate to the financial investment required to set up a PED. In Spain, two main barriers have already been identified: the high costs of a distributed system [1], and the current energy auction system which might discriminate smaller citizens initiatives in favor of larger operators [13]. In the 
area of Social capital, barriers include issues of unequal participation [63] and engrained patterns of energy consumption behaviors which may be difficult to change [64]. Research has also identified gender issues with women voices being underrepresented within LEC initiatives [49]. Political and regulatory barriers relate to the political context. In Spain, the stagnation of the energy system under the oligopoly [65] has already been outlined together with regime resistance $[13,47]$. The regulatory framework (included under human capital) has been recognized as a significant barrier in the case of Spain [12], despite the recent legislative changes and the clear need for a supportive legal framework for LECs [12] and PEDs. Research conducted prior to the change in legislation (RD244 overturned the so-called "Tax on the Sun") paints an even bleaker picture of prior legislative barriers to LEC initiatives [66].

PEDs may bring many opportunities, and these can broadly be divided into environmental, technological, social, financial, political and legislative. From an environmental perspective (natural capital), there is general consensus on the high potential for significantly reduced greenhouse gas emissions in Spain and the EU $[1,46,67]$. Technological opportunities (physical capital) include a potential improvement in the efficiency of the energy system through local power generation as this will not need to be transported long distances [1], and a more resilient and adaptable energy system overall [26,63].

Social advantages and opportunities (social capital) that have been researched include the transformative potential of LECs [13], including increased social justice [47], reciprocity and added co-activities $[26,63]$. Furthermore, there has been some research on the potential benefits of similar energy initiatives in rural areas of Spain [68]. Other research has examined the benefits of incorporating sustainability and renewable energy issues into school communities, through educational programs which often focus on energy consumption behavior change, but which also sometimes incorporate the installation of PV panels for self-consumption [69].

Financial opportunities (financial capital) include reducing national energy imports [70], improved competitiveness within the national energy market [12], which could be key to democratizing a new decentralized energy system [13], high rates of job creation, and benefits being shared between an increased number and range of actors [1]. Political and legislative opportunities (human capital) are seen as arising directly from European Directives [63] which means that the Spanish government is likely to encourage new forms of shared energy ownership [68].

Understanding that the current situation for PEDs positions firmly within the niche level, we examine each of the social opportunity spaces and what the barriers and opportunities for PEDs are with energy justice in mind, understanding that not all forms of energy justice will be displayed within each capital.

\section{Analysis of the Interviews}

In this section, we detail the results from our interviews, initially discussing problems with terminology, followed by three sections on physical and natural capital, financial capital, and human and social capitals. We then examine the barriers and opportunities in using PEDs that include LECs as tools to mitigate energy poverty.

\subsection{What Is a PED?}

A significant issue in terminology became clear in the interviews. All of the parties interviewed were involved in the field of energy, and yet almost all of them were unfamiliar with the term PED, including those working in districts that were listed in the PED booklet. Of the sixteen people interviewed, one city councilor in Viladecans was aware of the concept, and responded "Our idea is to produce an excess. For example, we are now implementing the action of PV panels in municipal facilities with the aid of the Ministry and that comes from Europe, and we are always looking for the maximum production. Why? Because we are looking for this model of producing excess energy that we can share with others. Our idea is in some cases to make bi-directional energy communities" (EC4, V1). A second councilor in the same interview 
$(E C 4$, V2) quickly interjected that the high energy demand from the industrial sector made it impossible for the entire town to become a PED. However, if the industrial area were to be excluded it would seem that the LECs in Viladecans (EC4) could be extended to form PEDs, or RET from outside the geographic area could be used to create a virtual PED. Conversely, during the interview with two PED designers from Valencia (PR1), it became clear that there is interest in the inclusion of LECs in the Valencia PED [71] after residents move in, with the potential for around $45 \%$ of energy needs to be met in this way. This demonstrates that the PED-LEC link could function both ways, with PEDS incorporating LECs, but also with the potential for LECs to amalgamate or grow to the point where they could be considered PEDs.

Only two of the researchers interviewed had heard of the term previously, but neither of them was familiar with its meaning (ER1, ER4). The interviewee from an energy related NGO (NGO1) understood PEDs as synonymous with LECs, highlighting the confusion over terminology "Our interpretation is energy communities, which we are promoting as a representative organization of people with concerns about the environment, not only that it is renewable and clean energy-but that we are working to reduce and even completely eliminate fossil fuels ... but also the opportunity to democratize the energy system" (NGO1). Another interviewee from a Cooperative (C1) believed that rather than a surplus of energy, PEDs/LECs could grow in size to match production by incorporating more residents, and that the borders of a PED or LEC could be malleable. This goes beyond current notions of PEDs replication [17,72], which assume fixed boundaries, and could provide an interesting and viable means of growing and up-scaling PEDs for the future. Once a definition of PEDs had been given, one town councillr (P1) said: "we have no interest in becoming a PED, absolutely not, because we do not want to have any surplus energy that goes to the supplier. What we really want to do is make sure that our consumption is met almost completely by our own production, but no more than that. If you are not a distributor then it really needs to be about meeting your energy needs and nothing more." (P1).

This seems to indicate that the low price currently given to excess energy sold to the grid from forms of prosumership (both individual and collective) is a significant barrier when it comes to encouraging the creation of PEDs which by their very definition are meant to produce a surplus. This could be remedied through direct government policy. It seems that the term PED has not fully entered into the vocabulary of experts, and there may be good grounds for policymakers to engage in a media campaign in order to make the term more familiar, at least in the case of Spain. Whilst LECs in Spain can be situated within the niche currently according to the MLP, it seems that PEDs are perhaps in a pre-niche state, where they are still yet to be formed in such a way as to enter the niche, let alone the regime level, despite the pressure from the landscape. This may change in the near future as the term PED may evolve according to how it is used across different EU countries.

\subsection{Physical Capital and Natural Capital-The Infrastructure and Environment}

Geographical and climatic conditions make solar energy be the most common renewable energy source used for the creation of PEDs in Spain. Conversely, windfarms are often seen as contentious [55] due to acceptance issues which are sometimes portrayed as NIMBYism [73]. However, there has been some energy justice research which suggest that increasing citizen participation can lead to greater acceptance in places where this is possible [74]. One LEC in Andalusia (EC1) rued the fact that in the past the community was able to create its own hydro-energy system but water levels were no longer reliable enough to make this possible, showing the negative impact of climate change on intergenerational energy justice. In a town in Navarra (EC2), an old abandoned hydro-electric plant was restored, but this was only possible because local water rights had been maintained for irrigation purposes, allowing the use of the water. In two other cases, a UNESCO world heritage town, and a mediaeval walled town, PV was not permitted within the center, but according to ER1, large scale PV farms are planned in the surrounding area. As NGO1 highlighted, a just energy strategy is needed: "In Spain, there are a lot of useful materials for 
renewables, however, they are opening many licenses and many prospections for open-cast mines, and this of course destroys biodiversity, the landscape, and so on".

In terms of distributional justice, having suitable natural capital is a prerequisite to installing physical capital such as PV. Home-owners may be more likely to opt for becoming individual prosumers, whilst those in rented or multi-occupancy accommodation may not have the legal right to install PVs, increasing energy inequalities. According to P1, the town of Soto del Real in Madrid reported that since the overturning of RD900/2015, the number of homes installing PV in the town has increased, from 2 in 2018, to 9 in 2019, to 22 in 2020, to over 20 in the first 3 months of 2021, meaning that RET might well be reaching the point of becoming an established part of the regime. In order to counter existing inequalities, multiple respondents explained that they relied on the local authorities to cede the roofspace of public buildings, such as schools (EC1), abandoned buildings (EC2), sports centers (P1, E4). Interviewee C1 suggested making suitable private roofs (i.e., industrial estates or office buildings) available to produce energy for those who need it the most: "I think that it is even an obligation for all of us who live in a built environment in cities, in towns, in villages, to make the most of the space that we already have, that is not being used to generate energy" (C1).

Some policymakers from local authorities (P1 and E4) were already engaged in this, and encouraging such engagement could greatly reduce distributional energy injustices in this form of physical capital. Using surplus energy generated on local authority buildings for LECs was seen as preferable to creating a surplus instead of giving it to the grid for a fraction of what it was sold on for (P1).

A further form of physical (and natural) capital is district heating and cooling (DH), and three of the official Spanish PED-like cases include or center around this. DH used to be commonplace but were replaced in a concerted campaign which one interviewee perceived as "A real social scam in my opinion, because what is really efficient are the centralized systems for community and for security." (P2, Mo2). Returning to more prevalent use of DH may reduce overall costs and reduce energy poverty, but the installation of DH in existing districts is costly and disruptive.

The developer who set up a DH network in Mostoles, Madrid using biomass, is currently applying for permission for a further $\mathrm{DH}$ which will be combined with the creation of some form of LEC, potentially in connection with solar assisted DH [75,76], but this once again raises issues of energy justice. How are the benefits and burdens going to be distributed when a private firm manages it? Are there barriers to citizen participation? How transparent are the processes connected with this? It seems clear that having a third party assist or take control and develop LECs within a PED may make things substantially easier for residents, but there are more questions than answers when it comes to exactly how this is to take place. According to P2 Mo2: "It has to be someone who, for example, in this case like (Company name), who presents them with the idea, who is willing to receive it, who has to stay, who has to adapt it".

Community energy storage has been researched [77] but this is in its infancy in Spain. In the interviews none of the LECs or PEDs had made any arrangements for energy storage due to its perceived cost and complexity. "We have ruled out storage also for simplicity" (EC3).

Resistance to the idea of energy storage seems to imply that this is a barrier for the creation of autarchic PEDs which do not rely on energy imports at all, "In fact, you're going to need batteries, you're going to need storage, in other words, you're already entering into a scheme that in the end, in order to buy in isolation, all this material is going to be much more expensive." (ER2,). However, this barrier disappears when one considers the fact that PEDs can be autonomous, dynamic or virtual [10]. Dynamic PEDs need to produce an annual net surplus but are also able to import energy (i.e., at night for those that rely on PV, and virtual PEDs can take advantage of larger scale storage solutions such as the wind-pumped hydropower station on El Hierro [78], or combine different forms of renewable energy in order to reduce intermittency, such as hydro, wave and wind [79,80]. Furthermore, innovative solutions to the issue of energy storage have been implemented in the PED in 
Évora, Portugal, where the use of second life batteries from electric vehicles is currently being tested [81].

Overall, it would appear, that local barriers connected to the physical and natural capitals of PEDs and LECs are not insignificant, but their local nature might be overcome by harnessing the ingenuity of residents to find viable solutions. From the interviews, the ceding of public roof space presents novel opportunities for existing natural capital to be harnessed for the creation of justice-informed PEDs.

\subsection{Financial Capital: Barriers and Opportunities}

The high initial costs involved in purchasing and installing the necessary technology to create LECs and PEDs may make the involvement of multiple private and public partners essential. One issue identified through our interviews concerning financial capital relates to intergenerational justice: "In the end if we make this type of system, a critical mass of consumers with the possibility of paying their electricity bill to the grid are not going to do so in the long term" (ER2). This means that if large numbers of people create microgrids, this could lead to underfunding of the national grid and, consequently, threaten national energy security. On the other hand, the benefits of a decentralized energy system using LECs on national energy security may well exceed any potential downside, i.e., PEDs could incorporate mixed forms of energy ownership which would allow continued payments to the grid, albeit on a reduced scale.

Although overall increases to grid costs have been considered in the literature [12], a novel significant barrier for PEDs that include LECs is that there is no organization nor group with any financial incentive to support their development. Although energy cooperatives are largely supportive, there is little benefit to cooperatives in assisting in the setting up of LECs. A member of the Som Energia cooperative (EC1) noted that some years ago they were almost the only option for consumers who wanted renewable energy. Now, LECs have to compete with the potential of people to become prosumers, with cooperatives, and with renewable models from all the major existing energy providers (e.g., [82,83]), all of which can be incorporated into PEDs albeit with differing outcomes in terms of a just transition. However, there seems to be ample evidence that cooperatives such as Som Energia, and NGOs such as Amigos de la Tierra, have been instrumental in supporting the creation of LECs [84]. One interviewee went on to say "We would never have started anything of what I'm telling you if it hadn't been for the initial, disinterested and altruistic support, and without anything asked for in return, from Som Energí" (EC1).

The use of a facilitator was seen as crucial for the planning of LECs [85], connecting financial capital with human and social capitals. When it comes to PEDs, could LECs and cooperatives be financially supported to co-create such districts?

\subsection{Human and Social Capitals}

The opaqueness of the energy market is perceived as a significant and deliberate barrier, with some LECs setting up energy advice centers as a major part of their activities (EC1, EC2, EC3) because energy bills and different tariffs are hard for consumers to understand. In terms of procedural justice, some interviewees went as far as suggesting that false or deliberately confusing information is given by the major utility companies (NGO1). Energy advice centers have been used to alleviate energy poverty [86] (See Section 4.5), and having these services embedded within the local community through LECs may contribute to their efficacy [87], particularly if the advice is given face-to-face [88].

The "...asymmetry of information" (ER2) is seen as a way of ensuring that consumers settle for simpler contracts that may well be more expensive (EC1, EC2, EC3). Embedding energy advice centers in PEDs may have an effect in creating energy literate prosumers who are better able to make decisions regarding their own energy consumption. This becomes all the more important from the 1 June 2021 in Spain, as a new energy tariff (The new electricity tariff which starts on the 1 June in Spain will mean that consumers will pay different amounts depending on the time of use; valley $(13.49 / \mathrm{Kwh}$, plain $(17.95 / \mathrm{kwh})$, and peak $(30.12 / \mathrm{Kwh})$. 
However, the fixed part of electricity bills will also be reduced. [89]. It was implemented, promoting households' energy behavior: "The new electricity tariff has a very clear rationale, I mean, change in behavior, rationale, and that's why it is very problematic" (EC4). Although there seems to be some concern that energy poverty and issues of recognitional energy justice will increase with the new tariff, it might be possible that the electricity prices increase " ... may motivate people to engage, to get together for a community energy project" (EC4).

Research has suggested that LECs may assist in overcoming indifference or uncertainty [90], and it may also be the case that current state of uncertainty and change in the Spanish energy sector with the new pricing system acts as a catalyst for promoting PED creation that includes community energy initiatives. However, a further significant barrier is that there are no "turn-key" models for LECs. Creating a PED that incorporates LECs is likely to involve a significant investment in time and effort which may simply not be feasible for many people. In contrast, consumers can sign up for a "green" energy supply, provided by most major suppliers, which does not involve any additional time, effort or knowledge. This might mean that there are some intragenerational justice issues, as the demographic that tends to be attracted to LECs may be younger people without families, or retired people with more time on their hands (C1). When it comes to PED creation, incorporating LECs may increase energy justice, but it is likely that a model in which community energy initiatives are pre-established in conjunction with either cooperatives or major energy suppliers will be simpler for the end user.

Furthermore, there is a lack of awareness on how the energy system works in Spain and what the new laws are, with an enduring negative social effect related to the former regressive "Sun Tax" (RD900/2015) which was widely publicized. One interviewee voiced that "there wasn't strong enough publicity to reverse that "(EC3), and that even though there are now EU directives that help enshrine LECs legal position, they have encountered a fear that government policies could be reversed from some prospective members. This fear and lack of awareness on how the energy system works is further exacerbated by the rapid speed of change in the current energy system. The uncertainty caused by rapid change and confusing terminology is enhanced by a perception that the energy industry is corrupt, with an EU survey showing that $86 \%$ of Spaniards believe corruption to be a big problem [91] and a third believing that it has increased in 2020 [92]: "Historically it is very, very corrupt. We have many former presidents and former ministers working on the boards of directors of the big electricity companies when they finish in office. This means that, well, governments directly legislate in favor of these companies" (EC4, V2). Indeed, a simple internet search reveals multiple newspaper articles highlighting recognitional justice issues such as a revolving door between politics and the major utility companies [93,94], as well as more recent articles with allegation of corruption and price fixing $[95,96]$. One interviewee (EC1) noted that a change in supplier had resulted in a technician knocking on their door and threatening them the next day, and that this gave them the additional impetus that they needed to go ahead and start to create a LEC.

There is widespread consensus on the need for greater citizen participation in the energy sector [97], and influences on community engagement in renewable energy projects in Spain, such as on the Island of La Graciosa [80], indicating that a pre-existing sense of community might have an effect, as do attitudes and norms, and awareness of other similar projects. This last point may indicate that there are tipping points that can be reached in LEC participation once it has become sufficiently diffuse, potentially leading to change at the regime level. Encouraging participation is no easy task: "everyone wants participation to be established, but then, when it comes down to it, getting this participation to be real and effective is not easy. You have to constantly encourage this participation and find actors who really want to participate" (EC4, V1).

In one PED project near Valencia [71], participation in the early stages of the co-design of the district involved numerous meetings, but interviewees from this project expressed how difficult it was to encourage longer term attendance, when these meetings would be scheduled for after work hours or at weekends, and people simply cannot be expected to 
volunteer significant amounts of time on a regular basis. This is even more so for vulnerable households who may need some assistance in participating [98]. In the later stages of cocreation, participants were asked to pay a $€ 600$ deposit towards accommodation in a district which may take several years to be created, raising potential issues of recognitional justice (PR1). Participation and reaching a consensus within the community on what is to be done, by whom, how, and how the benefits are to be shared, is no easy matter. Reaching agreement, even within a small block of flats is perceived as difficult: "if we don't agree on storing bikes downstairs in the (shared) entranceway, I doubt we will agree" (ER2). Existing conflicts between neighbors over shared spaces coupled with the complexity of LEC and PED creation may mean that some kind of neutral third party or intermediary is crucial if they are to succeed.

There are numerous social benefits to PED creation, beyond energy, which were mentioned in different interviews, for instance, increasing a local circular economy as in the case of Viladecans in Catalonia which created a local currency [99], and built a sense of community as a starting point for discussions on community mobility, community gardening and more; "Energy is like an excuse to get in the same boat... all on the same course, with the same objectives" (EC2). Similarly, one interviewee used the metaphor of planting tomatoes: "It's the metaphor we use for energy. If we plant tomatoes and we share them, why don't we plant energy? Because we're going to plant kilowatts. Yes, and share it" (EC1). Increasing a shared community beyond energy enables further distributional, recognitional and procedural justice issues to be considered and resolved within the community. This also opens up the possibility for restorative justice to be applied, when necessary, which may be most visible with the use of this type of initiative to counter energy poverty.

\subsection{PEDs and Energy Poverty}

Energy poverty encompasses multiple energy injustices [100-102], and Spain has a National Strategy [103] which defines energy poverty mainly as a consequence of low incomes and energy-inefficient housing. The National Strategy uses four main indicators to determine who falls into energy poverty, which are sourced from the European Energy Poverty Observatory (EPOV) [104]. The National Strategy identified between 3.5 to 8.1 million people living in energy poverty in Spain in 2019, setting a target of 50\% reduction in energy poverty by 2025 [103].

Methods that have been identified and are used in Spain to deal with energy poverty include a focus on consumer advice improvements, greater consumer protection, structural energy-efficiency measures and short-term financial assistance, such as the Social Tariff [105]. The use of rooftop PV to alleviate energy poverty has been considered in Spain [106], but potential community ownership of PV has not been fully addressed. Furthermore, PED projects such as "Making-city" in León, specifically target lower income neighborhoods for establishing PEDs [107] in order to mitigate energy poverty through energy efficiency improvements and RET.

The Social Tariff was set up in 2009 for electricity and 2018 for heating, and provides a discount for vulnerable families of either $25 \%$ or $40 \%$ on the electricity price (but not on fixed standing charges). This discount is available to vulnerable families directly from eight utility companies and was given to over 1.3 million households in 2020 [108]. It also includes extended payment periods (consumers are given four months to pay instead of the usual two), simplified bills, and some disconnection protection. However, it does not address the underlying causes of energy poverty, which has not decreased despite the Social Tariff [109].

Moreover, there is no means for other organizations, outside of the eight major utility companies, to offer the Social Tariff, which creates a powerful barrier countering the participation of those suffering from energy poverty in LECs, cooperatives, and, potentially, PEDs. Despite this, there is some evidence that some people who suffer from energy poverty still prefer to be members of an energy cooperative or LEC, even if this means that they do not receive the Social Tariff [109-111]. Nevertheless, the inclusion of energy 
vulnerable households in LECs and cooperatives is likely to be severely impaired if these are not able to offer the Social Tariff, and this will have repercussions on PEDs which include these forms of community energy initiatives.

From our interviews, it became clear that excluding LEC initiatives from the Social Tariff is a significant issue when it comes to the use of these to mitigate energy poverty within PEDs, "if being part of an energy community project means you cannot access the Social Tariff and the associated protection, that means that it's not a very good solution for the household in energy poverty" (EC4). Furthermore, this also puts LECs at a disadvantage compared to similar forms of shared energy ownership which are managed by the major utility companies. This was also raised in an interview with an energy researcher who noted that "the issue of costs is contradictory because in the end the best offer, as happened with our neighbor, is being given by Endesa or Repsol" (ER2).

The Social Tariff's issue does not stop LECs from having a focus on energy poverty, indeed, a researcher involved in the creation of LECs in Northern Spain said: "We work from the perspective of how energy communities can help or can be a tool to solve fuel poverty" (ER3). This was repeated throughout the interviews with a general consensus that even without the Social Tariff, LECs can help reduce future vulnerability to energy poverty and can also have an effect on those in energy poverty. The NGO involved in assisting in the creation of LECs went as far as to say that they believed that when it comes to energy poverty, LEC creation "could even be the solution" (NGO1). Similarly, ER2 said: "I see that energy communities could be another vehicle to also solve energy poverty.".

There is no doubt that there is an opportunity for PEDs that incorporate LECs to become a part of a new strategy for energy poverty mitigation in Spain, replicating the situation in other countries. However, owing to the current situation with the Social Tariff, it is likely that utility owned energy initiatives within PEDs may be better suited at mitigating energy poverty, and that a legislative change is needed if other energy initiatives are to be as successful. In the case of the UK, research has been conducted on how energy poverty can be alleviated through the use of novel business models which allow citizen participation in the energy market beyond individual prosumer, specifically considering social housing and multi-occupancy buildings [112]. However, this also recognizes the need for support from third party intermediaries [113] who may be able to help arrange buy-as-you-use arrangements, which are affordable and available to a greater part of the population.

Tackling energy poverty may create some tension with decarbonization aims, as energy consumption can end up increasing [114]. This was reported as the case in Vildecans in Catalonia, where energy poverty mitigation policies (including installing heating systems) led to an increase in energy consumption despite these being combined with energyefficiency measures and full retrofitting, including façade and windows (EC4).

\section{Conclusions}

This work shows the potential role that PEDs that incorporate LECs could play in decarbonizing and perhaps more significantly democratizing the energy system [115]. LECs have been embedded in EU policy, but PEDs are still very new concepts and need to be fully embedded in national and regional policies, as there is no official national strategy yet. There seem to be clear regional differences in Spain which may reflect political differences, as well as urban-rural differences, which may be exacerbated as urban areas are growing rapidly [116].

PEDs could contribute to a just transition in Spain, but there are significant barriers, such as energy illiteracy, and a lack of trust and awareness, which need to be overcome in order for this to be the case. The main strategies that this work proposes to address existing barriers are: Firstly, there may be good grounds for policymakers to engage in a media campaign in order to make the term more familiar to the general population. Secondly, although available technology is enough for considerable gains to be made in decarbonization through PED creation, the added benefits, such as energy poverty reduction, make these interesting propositions to be considered in tandem with the creation 
of larger scale RET farms. Finally, note that to truly harness the energy poverty mitigating benefits of PEDs and LECs, legislative changes may need to occur. In this respect, the current Social Tariff limits the inclusion of those most vulnerable in community initiatives of this type, thus, allowing LECs, PEDs and cooperatives to offer this could greatly increase their social impact. There may be a need to consider a move of energy poverty mitigation from social policy to energy policy [117], where incorporating LECs and PEDs into the arsenal of mitigation tools makes most sense, as the opportunity for synergies [118] between energy poverty mitigation and climate change mitigation can be better taken advantage of.

In conclusion, policymaker engagement in PED creation is crucial if these are to be successfully implemented. There is a clear opportunity to explore the use of LEC initiatives in tandem with PED creation, leading to multiple benefits in the future.

Author Contributions: Conceptualization, A.X.H. and R.C.-R.; Methodology, A.X.H. and R.C.-R.; Formal Analysis, A.X.H.; Investigation, A.X.H.; Data Curation, A.X.H.; Writing-Original Draft Preparation, A.X.H.; Writing-Review \& Editing, A.X.H. and R.C.-R.; Visualization, A.X.H. and R.C.R.; Supervision, R.C.-R. All authors have read and agreed to the published version of the manuscript.

Funding: This project has received funding from the European Union's Horizon 2020 research and innovation programme under the Marie Skłodowska-Curie Actions, Innovative Training Networks, Grant Agreement No 812730. Authors acknowledge the support for this work provided by the EPIU-Energy poverty intelligence unit (Funded by UE-European Regional Development Fund, UIA04-212 (EPIU).

Institutional Review Board Statement: The study was conducted according to the guidelines of the Declaration of Helsinki, and approved by the SMART-BEEjS Ethical Advisory Board, Application number: Smart-BEEjS-Basel-18032021, Approved 27 April 2021.

Informed Consent Statement: Informed consent was obtained from all subjects involved in the study.

Data Availability Statement: The data presented in this study will be openly available as anonymized transcripts in a repository, after the initial scientific article is accepted for publication, in the social sciences studies portal for Switzerland, (https://forsbase.unil.ch/ accessed on 30 June 2021, ref. study 14089).

Conflicts of Interest: The authors declare no conflict of interest.

\section{References}

1. Gallego-Castillo, C.; Heleno, M.; Victoria, M. Self-Consumption for Energy Communities in Spain: A Regional Analysis under the New Legal Framework. Energy Policy 2021, 150, 112144. [CrossRef]

2. Girard, A.; Gago, E.J.; Ordoñez, J.; Muneer, T. Spain's Energy Outlook: A Review of PV Potential and Energy Export. Renew. Energy 2016, 86, 703-715. [CrossRef]

3. Civiero, P.; Pascual, J.; Arcas Abella, J.; Bilbao Figuero, A.; Salom, J. PEDRERA. Positive Energy District Renovation Model for Large Scale Actions. Energies 2021, 14, 2833. [CrossRef]

4. Bossi, S.; Gollner, C.; Theierling, S. Towards 100 Positive Energy Districts in Europe: Preliminary Data Analysis of 61 European Cases. Energies 2020, 13, 6083. [CrossRef]

5. SETIS. SET Plan Information System. Setplan_Smartcities_Implementationplan.Pdf. Available online: https://setis.ec.europa.eu/ index_en (accessed on 20 June 2021).

6. EXCESS. PEB Case Studies. Available online: https:/ / positive-energy-buildings.eu/peb-case-studies (accessed on 16 March 2021).

7. Villa-Arrieta, M.; Sumper, A. Economic Evaluation of Nearly Zero Energy Cities. Appl. Energy 2019, 237, 404-416. [CrossRef]

8. Gollner, C. Europe towards Positive Energy Districts. 182. Urban Europe. Available online: https://jpi-urbaneurope.eu/wpcontent/uploads/2020/06/PED-Booklet-Update-Feb-2020_2.pdf (accessed on 20 June 2021).

9. Bilbao. ATELIER. Available online: https://smartcity-atelier.eu/about/lighthouse-cities/bilbao/?cn-reloaded=1 (accessed on 13 July 2021).

10. Lindholm, O.; Rehman, H.u.; Reda, F. Positioning Positive Energy Districts in European Cities. Buildings 2021, 11, 19. [CrossRef]

11. Directive (EU) $2018 / 2001$ of the European Parliament and of the Council of 11 December 2018 on the Promotion of the Use of Energy from Renewable Sources (Recast). EUR-Lex. Available online: https://eur-lex.europa.eu/legal-content/EN/LSU/?uri= uriserv:OJ.L_.2018.328.01.0082.01.ENG (accessed on 22 April 2021).

12. Inês, C.; Guilherme, P.L.; Esther, M.-G.; Swantje, G.; Stephen, H.; Lars, H. Regulatory Challenges and Opportunities for Collective Renewable Energy Prosumers in the EU. Energy Policy 2020, 138, 111212. [CrossRef] 
13. Capellán-Pérez, I.; Campos-Celador, Á.; Terés-Zubiaga, J. Renewable Energy Cooperatives as an Instrument towards the Energy Transition in Spain. Energy Policy 2018, 123, 215-229. [CrossRef]

14. Roberts, J.; Frieden, D.; d'Herbemont, S. Energy Community Definitions. 13. Available online: https://www.compile-project.eu/ wp-content/uploads/Explanatory-note-on-energy-community-definitions.pdf (accessed on 20 June 2021).

15. Sokołowski, M.M. Renewable and Citizen Energy Communities in the European Union: How (Not) to Regulate Community Energy in National Laws and Policies. J. Energy Nat. Resour. Law 2020, 38, 289-304. [CrossRef]

16. Hedman, Å.; Rehman, H.U.; Gabaldón, A.; Bisello, A.; Albert-Seifried, V.; Zhang, X.; Guarino, F.; Grynning, S.; Eicker, U.; Neumann, H.-M.; et al. IEA EBC Annex83 Positive Energy Districts. Buildings 2021, 11, 130. [CrossRef]

17. Gabaldón Moreno, A.; Vélez, F.; Alpagut, B.; Hernández, P.; Sanz Montalvillo, C. How to Achieve Positive Energy Districts for Sustainable Cities: A Proposed Calculation Methodology. Sustainability 2021, 13, 710. [CrossRef]

18. Horstink, L.; Wittmayer, J.M.; Ng, K. Pluralising the European Energy Landscape: Collective Renewable Energy Prosumers and the EU's Clean Energy Vision. Energy Policy 2021, 153, 112262. [CrossRef]

19. user_administrator. Clean Energy for All Europeans Package. Available online: https:/ / ec.europa.eu/energy/topics/energystrategy / clean-energy-all-europeans_en (accessed on 11 March 2021).

20. Koirala, B.P.; van Oost, E.C.; van der Waal, E.C.; van der Windt, H.J. New Pathways for Community Energy and Storage; Multidisciplinary Digital Publishing Institute: Basel, Switzerland, 2021.

21. de Mier Cortijo, L.G.; Lopez, M.L.; Castaño-Rosa, R.; Hearn, A. Consulta Pública Previa Comunidades Energéticas Locales. Available online: https://hogaressaludables.getafe.es/wp-content/uploads/2021/01/Consulta-publica-Comunidades-Energ\% C3\%A9ticas.pdf (accessed on 20 June 2021).

22. El MITECO Abre el Proceso de Consulta Pública Previa Para el Desarrollo de Comunidades Energéticas Locales. Available online: https:/ / www.miteco.gob.es/es/prensa/ultimas-noticias/el-miteco-abre-el-proceso-de-consulta-p\%C3\%BAblica-previapara-el-desarrollo-de-comunidades-energ\%C3\%A9ticas-locales- / tcm:30-516684 (accessed on 28 June 2021).

23. Garriga, S.M.; Dabbagh, M.; Krarti, M. Optimal Carbon-Neutral Retrofit of Residential Communities in Barcelona, Spain. Energy Build. 2020, 208, 109651. [CrossRef]

24. Wiersma, B.; Devine-Wright, P. Decentralising Energy: Comparing the Drivers and Influencers of Projects Led by Public, Private, Community and Third Sector Actors. Contemp. Soc. Sci. 2014, 9, 456-470. [CrossRef]

25. Torabi Moghadam, S.; Di Nicoli, M.V.; Manzo, S.; Lombardi, P. Mainstreaming Energy Communities in the Transition to a Low-Carbon Future: A Methodological Approach. Energies 2020, 13, 1597. [CrossRef]

26. Rodríguez, A.S. Potenciales de La Energía Distribuida En España; Revista de Obras Públicas: Organo Profesional de los Ingenieros de Caminos, Canales y Puertos: Madrid, Spain, 2017; pp. 8-19.

27. Gjorgievski, V.Z.; Cundeva, S.; Georghiou, G.E. Social Arrangements, Technical Designs and Impacts of Energy Communities: A Review. Renew. Energy 2021, 169, 1138-1156. [CrossRef]

28. Caramizaru, A.; Uihlein, A. Energy Communities: An Overview of Energy and Social Innovation; Publications Office of the European Union: Luxembourg, 2020.

29. Castaño-Rosa, R.; Solís-Guzmán, J.; Marrero, M. Energy Poverty Goes South? Understanding the Costs of Energy Poverty with the Index of Vulnerable Homes in Spain. Energy Res. Soc. Sci. 2020, 60, 101325. [CrossRef]

30. Thomson, H.; Bouzarovski, S.; Snell, C. Rethinking the Measurement of Energy Poverty in Europe: A Critical Analysis of Indicators and Data. Indoor Built Environ. 2017, 26, 879-901. [CrossRef]

31. Savelli, I.; Morstyn, T. Better Together: Harnessing Social Relationships in Smart Energy Communities. Energy Res. Soc. Sci. 2021, 78, 102125. [CrossRef]

32. Hanke, F.; Lowitzsch, J. Empowering Vulnerable Consumers to Join Renewable Energy Communities-Towards an Inclusive Design of the Clean Energy Package. Energies 2020, 13, 1615. [CrossRef]

33. Lee, J.; Kim, H.; Byrne, J. Operationalising Capability Thinking in the Assessment of Energy Poverty Relief Policies: Moving from Compensation-Based to Empowerment-Focused Policy Strategies. J. Hum. Dev. Capab. 2021, 22, 292-315. [CrossRef]

34. Douvitsa, I. The new law on energy communities in Greece. Coop. Econ. Soc. 2018, 40, 31-58. [CrossRef]

35. García, G.F.; Frantzeskaki, M. Las comunidades energéticas en Grecia. REVESCO Rev. Estud. Coop. 2021, 137, 57-72.

36. Barroco Fontes Cunha, F.; Carani, C.; Nucci, C.A.; Castro, C.; Santana Silva, M.; Andrade Torres, E. Transitioning to a Low Carbon Society through Energy Communities: Lessons Learned from Brazil and Italy. Energy Res. Soc. Sci. 2021, 75, 101994. [CrossRef]

37. Algarvio, H. The Role of Local Citizen Energy Communities in the Road to Carbon-Neutral Power Systems: Outcomes from a Case Study in Portugal. Smart Cities 2021, 4, 840-863. [CrossRef]

38. Koirala, B.P.; Koliou, E.; Friege, J.; Hakvoort, R.A.; Herder, P.M. Energetic Communities for Community Energy: A Review of Key Issues and Trends Shaping Integrated Community Energy Systems. Renew. Sustain. Energy Rev. 2016, 56, 722-744. [CrossRef]

39. Gouveia, J.P.; Seixas, J.; Palma, P.; Duarte, H.; Luz, H.; Cavadini, G.B. Positive Energy District: A Model for Historic Districts to Address Energy Poverty. Front. Sustain. Cities 2021, 3, 16. [CrossRef]

40. Ajanovic, A.; Hiesl, A.; Haas, R. On the Role of Storage for Electricity in Smart Energy Systems. Energy 2020, $200,117473$. [CrossRef]

41. Østergaard, P.A.; Johannsen, R.M.; Lund, H.; Mathiesen, B.V. Latest Developments in 4th Generation District Heating and Smart Energy Systems. Int. J. Sustain. Energy Plan. Manag. 2021, 31, 1-4. 
42. Ahmad, T.; Zhang, D. Using the Internet of Things in Smart Energy Systems and Networks. Sustain. Cities Soc. $2021,68,102783$. [CrossRef]

43. López Prol, J.; Steininger, K.W. Photovoltaic Self-Consumption Is Now Profitable in Spain: Effects of the New Regulation on Prosumers' Internal Rate of Return. Energy Policy 2020, 146, 111793. [CrossRef]

44. Som Energia / La Cooperativa d'Energia Verda. Available online: https://www.somenergia.coop/ca/ (accessed on 29 March 2021).

45. Cuesta-Fernandez, I.; Belda-Miquel, S.; Calabuig Tormo, C. Challengers in Energy Transitions beyond Renewable Energy Cooperatives: Community-Owned Electricity Distribution Cooperatives in Spain. Innov. Eur. J. Soc. Sci. Res. 2020, 33, 140-159. [CrossRef]

46. Kunze, C.; Becker, S. Collective Ownership in Renewable Energy and Opportunities for Sustainable Degrowth. Sustain. Sci. 2015, 10, 425-437. [CrossRef]

47. Pinker, A.; Argüelles, L.; Fischer, A.; Becker, S. Between Straitjacket and Possibility: Energy Initiatives and the Politics of Regulation. Geoforum 2020, 113, 14-25. [CrossRef]

48. Day, R.; Walker, G.; Simcock, N. Conceptualising Energy Use and Energy Poverty Using a Capabilities Framework. Energy Policy 2016, 93, 255-264. [CrossRef]

49. Lieu, J.; Sorman, A.H.; Johnson, O.W.; Virla, L.D.; Resurrección, B.P. Three Sides to Every Story: Gender Perspectives in Energy Transition Pathways in Canada, Kenya and Spain. Energy Res. Soc. Sci. 2020, 68, 101550. [CrossRef]

50. Geels, F.W. Technological Transitions as Evolutionary Reconfiguration Processes: A Multi-Level Perspective and a Case-Study. Res. Policy 2002, 31, 1257-1274. [CrossRef]

51. Jenkins, K.; Sovacool, B.K.; McCauley, D. Humanizing Sociotechnical Transitions through Energy Justice: An Ethical Framework for Global Transformative Change. Energy Policy 2018, 117, 66-74. [CrossRef]

52. Dóci, G.; Vasileiadou, E.; Petersen, A.C. Exploring the Transition Potential of Renewable Energy Communities. Futures 2015, 66, 85-95. [CrossRef]

53. Sen, A. Commodities and Capabilities; Oxford University Press: Oxford, UK, 1999.

54. Arnaiz, M.; Cochrane, T.A.; Hastie, R.; Bellen, C. Micro-Hydropower Impact on Communities' Livelihood Analysed with the Capability Approach. Energy Sustain. Dev. 2018, 45, 206-210. [CrossRef]

55. Velasco-Herrejon, P.; Bauwens, T. Energy Justice from the Bottom up: A Capability Approach to Community Acceptance of Wind Energy in Mexico. Energy Res. Soc. Sci. 2020, 70, 101711. [CrossRef]

56. Fernández-Baldor, Á.; Boni, A.; Lillo, P.; Hueso, A. Are Technological Projects Reducing Social Inequalities and Improving People's Well-Being? A Capability Approach Analysis of Renewable Energy-Based Electrification Projects in Cajamarca, Peru. J. Hum. Dev. Capab. 2014, 15, 13-27. [CrossRef]

57. A European Green Deal. Available online: https://ec.europa.eu/info/strategy/priorities-2019-2024/european-green-deal_en (accessed on 18 June 2021).

58. Jenkins, K.; McCauley, D.; Heffron, R.; Stephan, H.; Rehner, R. Energy Justice: A Conceptual Review. Energy Res. Soc. Sci. 2016, 11, 174-182. [CrossRef]

59. Hearn, A.X.; Sohre, A.; Burger, P. Innovative but Unjust? Analysing the Opportunities and Justice Issues within Positive Energy Districts in Europe. Energy Res. Soc. Sci. 2021, 78, 102127. [CrossRef]

60. McCauley, D.; Ramasar, V.; Heffron, R.J.; Sovacool, B.K.; Mebratu, D.; Mundaca, L. Energy Justice in the Transition to Low Carbon Energy Systems: Exploring Key Themes in Interdisciplinary Research. Appl. Energy 2019, 233-234, 916-921. [CrossRef]

61. Mulvaney, D. Opening the Black Box of Solar Energy Technologies: Exploring Tensions Between Innovation and Environmental Justice. Sci. Cult. 2013, 22, 230-237. [CrossRef]

62. Guia_Para-Desarrollo-Instrumentos-Fomento_Comunidades_Energeticas_Locales_20032019_0.Pdf. Mapeo Normativa Energetica. Available online: https: / /www.scribd.com/ (accessed on 20 June 2021).

63. Atutxa, E.; Zubero, I.; Calvo-Sotomayor, I. Scalability of Low Carbon Energy Communities in Spain: An Empiric Approach from the Renewed Commons Paradigm. Energies 2020, 13, 5045. [CrossRef]

64. Axon, S.; Morrissey, J.; Aiesha, R.; Hillman, J.; Revez, A.; Lennon, B.; Salel, M.; Dunphy, N.; Boo, E. The Human Factor: Classification of European Community-Based Behaviour Change Initiatives. J. Clean. Prod. 2018, 182, 567-586. [CrossRef]

65. Balbás Egea, J.Á.; Eguren Egiguren, J.A. Bases for a Sustainable Energy Model. Case Study: Basque Autonomous Community. Int. J. Sustain. Energy 2019, 38, 884-903. [CrossRef]

66. Romero-Rubio, C.; de Andrés Díaz, J.R. Sustainable Energy Communities: A Study Contrasting Spain and Germany. Energy Policy 2015, 85, 397-409. [CrossRef]

67. Schram, W.; Louwen, A.; Lampropoulos, I.; van Sark, W. Comparison of the Greenhouse Gas Emission Reduction Potential of Energy Communities. Energies 2019, 12, 4440. [CrossRef]

68. Cabarcos, A.L.; Castro, N.R.; Viña, V.M. Autonomía Enerxética Local e Desenvolvemento Rural Sustentable: Análise Da Predisposición a Participar En Comunidades Enerxéticas Renovables. Rev. Galega Econ. 2020, 29, 141-166.

69. Lizana, J.; Manteigas, V.; Chacartegui, R.; Lage, J.; Becerra, J.A.; Blondeau, P.; Rato, R.; Silva, F.; Gamarra, A.R.; Herrera, I. A Methodology to Empower Citizens towards a Low-Carbon Economy. The Potential of Schools and Sustainability Indicators. J. Environ. Manag. 2021, 284, 112043. [CrossRef]

70. Camprubí, L. Whose Self-Sufficiency? Energy Dependency in Spain from 1939. Energy Policy 2019, 125, 227-234. [CrossRef] 
71. Vivir Aquí. La Pinada. Available online: https://www.barriolapinada.es/vivir-aqui/ (accessed on 20 June 2021).

72. Alpagut, B.; Akyürek, Ö.; Mitre, E.M. Positive Energy Districts Methodology and Its Replication Potential. Proceedings 2019, 20, 8. [CrossRef]

73. Leiren, M.D.; Aakre, S.; Linnerud, K.; Julsrud, T.E.; Di Nucci, M.-R.; Krug, M. Community Acceptance of Wind Energy Developments: Experience from Wind Energy Scarce Regions in Europe. Sustainability 2020, 12, 1754. [CrossRef]

74. Avila, S. Environmental Justice and the Expanding Geography of Wind Power Conflicts. Sustain. Sci. 2018, 13, 599-616. [CrossRef]

75. Abokersh, M.H.; Vallès, M.; Cabeza, L.F.; Boer, D. A Framework for the Optimal Integration of Solar Assisted District Heating in Different Urban Sized Communities: A Robust Machine Learning Approach Incorporating Global Sensitivity Analysis. Appl. Energy 2020, 267, 114903. [CrossRef]

76. Tulus, V.; Abokersh, M.H.; Cabeza, L.F.; Vallès, M.; Jiménez, L.; Boer, D. Economic and Environmental Potential for Solar Assisted Central Heating Plants in the EU Residential Sector: Contribution to the 2030 Climate and Energy EU Agenda. Appl. Energy 2019, 236, 318-339. [CrossRef]

77. Parra, D.; Swierczynski, M.; Stroe, D.I.; Norman, S.A.; Abdon, A.; Worlitschek, J.; O’Doherty, T.; Rodrigues, L.; Gillott, M.; Zhang, X.; et al. An Interdisciplinary Review of Energy Storage for Communities: Challenges and Perspectives. Renew. Sustain. Energy Rev. 2017, 79, 730-749. [CrossRef]

78. Gorona Del Viento. Gorona Del Viento El Hierro, S.A. Available online: https:/ / www.goronadelviento.es / (accessed on 18 June 2021).

79. Robertson, B.; Bekker, J.; Buckham, B. Renewable Integration for Remote Communities: Comparative Allowable Cost Analyses for Hydro, Solar and Wave Energy. Appl. Energy 2020, 264, 114677. [CrossRef]

80. Jelić, M.; Batić, M.; Tomašević, N.; Barney, A.; Polatidis, H.; Crosbie, T.; Abi Ghanem, D.; Short, M.; Pillai, G. Towards SelfSustainable Island Grids through Optimal Utilization of Renewable Energy Potential and Community Engagement. Energies 2020, 13, 3386. [CrossRef]

81. A Second Life for Batteries. POCITYF. Available online: https:/ / pocityf.eu/news/a-second-life-for-batteries / (accessed on 7 July 2021).

82. Nuestro Compromiso. Endesa. Available online: https://www.endesa.com/es/nuestro-compromiso (accessed on 27 May 2021).

83. Sustainability. Available online: https://www.iberdrola.com/sustainability (accessed on 27 May 2021).

84. Amigos de la Tierra. Comunidades Energéticas. Available online: https://www.tierra.org/comunidades-energeticas/ (accessed on 20 June 2021).

85. Hettinga, S.; Nijkamp, P.; Scholten, H. A Multi-Stakeholder Decision Support System for Local Neighbourhood Energy Planning. Energy Policy 2018, 116, 277-288. [CrossRef]

86. Martiskainen, M.; Heiskanen, E.; Speciale, G. Community Energy Initiatives to Alleviate Fuel Poverty: The Material Politics of Energy Cafés. Local Environ. 2018, 23, 20-35. [CrossRef]

87. Reeves, A. Exploring Local and Community Capacity to Reduce Fuel Poverty: The Case of Home Energy Advice Visits in the UK Energies 2016, 9, 276. [CrossRef]

88. Baker, K.J.; Mould, R.; Stewart, F.; Restrick, S.; Melone, H.; Atterson, B. Never Try and Face the Journey Alone: Exploring the Face-to-Face Advocacy Needs of Fuel Poor Householders in the United Kingdom. Energy Res. Soc. Sci. 2019, 51, 210-219. [CrossRef]

89. Así es la Nueva Tarifa de la Luz: Cuándo es Más Barata y Trucos Para Ahorrar en la Factura. Available online: https: //www.antena3.com/noticias/sociedad/cambio-tarifas-electricas-pagare-mas-cual-mejor-hora-usar-electrodomesticos_2021 053160b5b8c175307d0001ad95ed.html (accessed on 23 June 2021).

90. Bauwens, T.; Devine-Wright, P. Positive Energies? An Empirical Study of Community Energy Participation and Attitudes to Renewable Energy. Energy Policy 2018, 118, 612-625. [CrossRef]

91. El 86 \% de los Españoles ve la Corrupción Como un "Gran Problema”, Según TI. Available online: https://www.swissinfo.ch/ spa/corrupci\%C3\%B3n-espa\%C3\%B1a--previsi\%C3\%B3n-_el-86---de-los-espa\%C3\%B1oles-ve-la-corrupci\%C3\%B3n-comoun--gran-problema---seg\%C3\%BAn-ti/46705952 (accessed on 17 June 2021).

92. Global Corruption Barometer EU: People Worried about Unchecked Abuse of Power. Available online: https:/ / www.transparency. org/en/news/gcb-eu-2021-survey-people-worry-corruption-unchecked-impunity-business-politics (accessed on 17 June 2021).

93. Dirigentes, G. Puertas Giratorias: Más de 50 Políticos Enchufados a la Energía. Available online: https: / / dirigentesdigital.com/ hemeroteca/puertas_giratorias_mas_de_50_politicos_enchufados_a_la_energia-AVDD12013 (accessed on 17 June 2021).

94. 43 Políticos “Enchufados” En Eléctricas. Crónica. EL MUNDO. Available online: https://www.elmundo.es/cronica/2014/02/23 /530881d922601da2168b456c.html (accessed on 17 June 2021).

95. Herrera, E. Catorce ex Cargos Políticos se Sientan en los Consejos de Grandes Empresas Energéticas. Available online: https: //www.infolibre.es/noticias/politica/2018/08/28/expoliticos_empresas_sector_electrico_86148_1012.html (accessed on 17 June 2021).

96. El Gobierno Pide a Competencia Que Investigue a Las Eléctricas Por Una Posible Manipulación de Precios. Economía. Cadena SER. Available online: https://cadenaser.com/ser/2021/06/07/economia/1623088773_133664.html (accessed on 21 June 2021).

97. Koirala, B.P.; Araghi, Y.; Kroesen, M.; Ghorbani, A.; Hakvoort, R.A.; Herder, P.M. Trust, Awareness, and Independence: Insights from a Socio-Psychological Factor Analysis of Citizen Knowledge and Participation in Community Energy Systems. Energy Res. Soc. Sci. 2018, 38, 33-40. [CrossRef] 
98. Southwell, B.; Ronneberg, K.; Shen, K.; Jorgens, E.; Hazel, J.; Alemu, R.; Ross, J.; Richman, L.; Vermeer, D. Energy Information Engagement among the Poor: Predicting Participation in a Free Workshop. Energy Res. Soc. Sci. 2014, 4, 21-22. [CrossRef]

99. Sánchez-Bayón, A.; García-Ramos, M.Á. How to Undertake with Digital Currencies as Csr 3.0 Practices in Wellbeing Economics? J. Entrep. Educ. 2020, 23, 1-8.

100. Medios de Comunicación y Stakeholders: Contribución al Debate Público de La Pobreza y Justicia Energética En España/Media and Stakeholders: Contribution to the Public Debate on Poverty and Energy Justice in Spain. REIS 2019, 168, 73-92. [CrossRef]

101. Groves, C.; Shirani, F.; Pidgeon, N.; Cherry, C.; Thomas, G.; Roberts, E.; Henwood, K. 'The Bills Are a Brick Wall': Narratives of Energy Vulnerability, Poverty and Adaptation in South Wales. Energy Res. Soc. Sci. 2020, 70, 101777. [CrossRef]

102. Walker, G.; Day, R. Fuel Poverty as Injustice: Integrating Distribution, Recognition and Procedure in the Struggle for Affordable Warmth. Energy Policy 2012, 49, 69-75. [CrossRef]

103. Spanish National Strategy for Energy Poverty Miteco.gob.es. Available online: https://www.miteco.gob.es/es/ministerio/ planes-estrategias/estrategia-pobreza-energetica/ (accessed on 20 June 2021).

104. EU Energy Poverty Observatory. Available online: https://www.energypoverty.eu/eu-energy-poverty-observatory (accessed on 15 June 2021).

105. Bono Social de Electricidad. Available online: https:/ / www.bonosocial.gob.es/\#quees (accessed on 16 June 2021).

106. Romero Rodríguez, L.; Sánchez Ramos, J.; Guerrero Delgado, M.; Molina Félix, J.L.; Álvarez Domínguez, S. Mitigating Energy Poverty: Potential Contributions of Combining PV and Building Thermal Mass Storage in Low-Income Households. Energy Convers. Manag. 2018, 173, 65-80. [CrossRef]

107. City Profiles-Making City. Available online: http:/ / makingcity.eu/city-profiles/ (accessed on 18 July 2021).

108. Bono Social Eléctrico: ¿cómo le Afecta la Nueva Factura de la luz y las Franjas Horarias? Available online: https://as.com/ diarioas/2021/06/03/actualidad/1622724404_875070.html (accessed on 16 June 2021).

109. Alvarez, G.G.; Tol, R.S.J. The Impact of the Bono Social de Electricidad on Energy Poverty in Spain; Working Paper Series; Department of Economics, University of Sussex Business School: Brighton, UK, 2020.

110. Gabiola, E.J.; Gázquez, J.D.P.; Rodríguez, J.A.S. El Bono Social y Las Cooperativas Energéticas Verdes: Situación y Perspectivas. Revesco. Rev. Estud. Coop. 2016, 122, 165-190. [CrossRef]

111. Antepara, I.; Claeyé, F.; Lopez, A.; Robyns, B. Fighting against Fuel Poverty by Collaborating with Social Services through Energy Advice: An Innovative Case from Spain. Rev. Vasca Econ. Soc. 2020, 17, 71-96. [CrossRef]

112. Pitt, J.; Nolden, C. Post-Subsidy Solar PV Business Models to Tackle Fuel Poverty in Multi-Occupancy Social Housing. Energies 2020, 13, 4852. [CrossRef]

113. Saunders, R.W.; Gross, R.J.K.; Wade, J. Can Premium Tariffs for Micro-Generation and Small Scale Renewable Heat Help the Fuel Poor, and If so, How? Case Studies of Innovative Finance for Community Energy Schemes in the UK. Energy Policy 2012, 42, 78-88. [CrossRef]

114. Chakravarty, S.; Tavoni, M. Energy Poverty Alleviation and Climate Change Mitigation: Is There a Trade Off? Energy Econ. 2013, 40, S67-S73. [CrossRef]

115. Saintier, S. Community Energy Companies in the UK: A Potential Model for Sustainable Development in "Local" Energy? Sustainability 2017, 9, 1325. [CrossRef]

116. Boeri, A.; Longo, D.; Roversi, R.; Turci, G. Positive Energy Districts: European Research And Pilot Projects Focus on the Mediterranean Area. Sustain. Mediterr. Constr. 2020, 12, $22-27$.

117. Primc, K.; Slabe-Erker, R. Social Policy or Energy Policy? Time to Reconsider Energy Poverty Policies. Energy Sustain. Dev. 2020, 55, 32-36. [CrossRef]

118. López, A.N. A Rolex o a setas. Comunidades Autónomas, cambio climático y modelo económico. Rev. Catalana Dret Ambient. 2020, 11, 1-30. 